\title{
HORKHEIMER, MaX. Eclipse da razáo. Tradução de Carlos Henrique Pissardo. Sáo Paulo: Editora da UNESP, 2015, 207P.
}

Rafael Cordeiro Silva ${ }^{1}$

Em 1947, Max Horkheimer publica Eclipse of reason, uma obra que reuniu cinco conferências proferidas na Universidade Columbia, de Nova Iorque, em 1944, a convite do Departamento de Filosofia daquela Universidade. O prefácio data de março de 1946, um ano depois da rendição alemá, que se dera em março de 1945.

O conteúdo da obra não pode ser desconectado das experiências que seu autor vivenciara, desde sua saída da Alemanha, em 1933: a breve passagem pela Suíça e a chegada aos Estados Unidos, em 1934, a Segunda Guerra Mundial, o extermínio dos judeus, o destino das revoluções socialistas e a indústria cultural. Essas experiências determinaram um conteúdo bastante diferente, se comparado aos escritos iniciais do autor. Ele abandona o projeto do materialismo interdisciplinar dos primeiros anos e direciona sua atenção para a crítica dos pressupostos da racionalidade do ocidente. Outro aspecto importante a considerar é que as ideias contidas em Eclipse da razão têm suas bases em dois escritos: "Estado autoritário" (1942) e "O fim da razão" (1941, em inglês), republicado com o título "Razão e autoconservação" (1942, em alemão, com alguns acréscimos) - sobretudo neste último, pois é um texto que lida diretamente com o tema da razão.

\footnotetext{
1 Professor Titular do Instituto de Filosofia da Universidade Federal de Uberlândia (UFU), Uberlândia, MG - Brasil. (ID https://orcid.org/0000-0002-1580-7283 E-mail: rcsilva@ufu.br

Autor de Max Horkheimer: teoria crítica e barbárie (EDUFU, 2011) e artigos e capítulos de livros sobre temas e autores relacionados à teoria crítica da sociedade.
}

http://dx.doi.org/10.1590/0101-3173.2019.v42n1.12.p245 
Conforme relata Wiggershaus (2002, p. 374-375), em seu clássico estudo sobre a teoria crítica, Horkheimer confidenciara, em uma carta a Pollock, que Eclipse da razão seria uma espécie de versão popular da Dialética do esclarecimento. De fato, muitos dos temas expostos na Dialética ganham uma interpretação mais compreensível, no Eclipse. Mais do que isso, o cotejamento entre ambos os escritos revela o que, na Dialética, é de Horkheimer e o que é de Adorno. Os temas consagrados e recorrentes na filosofia de Horkheimer, os quais estavam diluídos na Dialética, ganham evidência no Eclipse da razão. Em linhas gerais, a motivação das duas obras é a mesma e aparece nos respectivos prefácios. É célebre a afirmação da Dialética de que o interesse da obra residia na tentativa de entender "por que a humanidade, em vez de entrar em um estado verdadeiramente humano, está se afundando em uma nova espécie de barbárie.” (ADORNO; HORKHEIMER, 1985, p. 11). De igual modo, Eclipse da razão descreve esse mesmo interesse, com outras palavras: "As potencialidades presentes de realização social superam as expectativas de todos os filósofos e estadistas que já esboçaram em programas utópicos a ideia de uma sociedade verdadeiramente humana. Ainda assim, [...] as esperanças do gênero humano parecem estar mais distantes de sua realização hoje do que nas hesitantes épocas em que elas foram formuladas pela primeira vez." (HORKHEIMER, 2015, p. 7-8).

O primeiro capítulo dessa obra, intitulado "Meios e fins", é uma discussão da Razão e das formas pelas quais ela se apresentou, ao longo da história humana. Aqui, o interlocutor de Horkheimer é Max Weber. O filósofo toma do sociólogo a distinção entre racionalidade formal e instrumental (Zweckrationalität), de um lado, e racionalidade valorativa (Wertrationalität), de outro, e trabalha os conceitos a partir de sua perspectiva. A ideia principal, desenvolvida no capítulo, é a de que o que chamamos razão é, na verdade, o resultado da prevalência de uma forma específica dela, a saber, como dominação da natureza e dos homens. Essa discussáo está presente na Dialética, mas, em Eclipse da razão, ela assume uma forma mais inteligível. Horkheimer analisa a razão enquanto dividida em duas faces - a objetiva e a subjetiva - e como a dimensão subjetiva eclipsou a objetiva. Ele vai à história da filosofia, para evidenciar a tese principal do capítulo.

Por razão objetiva pode-se entender "uma força não apenas na mente individual, mas também no mundo objetivo - nas relaçóes entre seres humanos e entre classes sociais, em instituiçóes sociais e na natureza e em suas manifestaçôes." Substituir por (HORKHEIMER, 2015, p. 12). Ela diz respei- 
to a valores e, nesse sentido, está bastante relacionada com a Wertrationalität proposta por Weber. Esse tipo de racionalidade está presente nas narrativas míticas, nas grandes religiôes e nos sistemas metafísicos de Platão a Hegel. Ele foi, ao longo da história, subsumido pela outra dimensão - a subjetiva - que é a forma pela qual a racionalidade se manifesta e que aparenta ser bastante razoável, pois corresponde ao que o senso comum entende pelo termo. A razão subjetiva de Horkheimer aproxima-se da Zweckrationalität weberiana. No plano específico dos conceitos, a razão subjetiva pode ser concebida como "a faculdade de classificação, inferência e dedução, não importando o conteúdo específico [...] Esse tipo de razão [...] está essencialmente preocupada com meios e fins." (HORKHEIMER, 2015, p. 11). A razão subjetiva é uma faculdade inerente ao sujeito, ela é responsável pelo pragmatismo da existência cotidiana, já que as açôes do indivíduo obedecem a uma lógica que busca, pelos meios mais adequados, tendo em vista os fins propostos. Mas essa razão também é denominada formal e instrumental. Sob esse aspecto, ela está ligada à dominação da natureza externa, tanto por meio de sua formalização e tradução em leis científicas quanto pelo desenvolvimento de meios técnicos e instrumentais, para a maior eficiência dessa dominação. Em última análise, todos os fins estariam orientados para a autoconservação da vida.

A razão objetiva era mais ampla do que a subjetiva, e esta era apenas expressão parcial daquela. Ao longo do capítulo, Horkheimer vai mostrando como ocorreu a inversão de primazia, com o consequente eclipsamento do aspecto objetivo da razão. Esse processo é histórico e está na raiz do que o autor denomina "crise cultural presente" (HORKHEIMER, 2015, p. 8, 69). $\mathrm{O}$ eclipsamento da racionalidade objetiva remonta aos primórdios da civilização ocidental, mas se acentuou no Século das Luzes, pela crítica às ilusões propagadas pela religião. Esta foi a principal responsável pela destruição da objetividade da razáo. O Iluminismo queria atacar a religião, todavia, acabou por destruir a metafísica e o conceito objetivo de razão, lamenta o autor (HORKHEIMER, 2015, p. 26).

O capítulo 2, intitulado "Panaceias conflitantes", aborda um tema que não é novo, no pensamento de Horkheimer. É a discussão das correntes filosóficas às quais a teoria crítica se opôe: o positivismo lógico e a metafísica. Desde "Observaçôes sobre ciência e crise", "Hegel e o problema da metafísica", publicados em 1932, o questionamento a essas tendências filosóficas contemporâneas tem aparecido nos escritos do autor, de maneira velada ou explícita. $\mathrm{O}$ mesmo se deu também com Adorno. Basta lembrar 
sua aula inaugural, "A atualidade da filosofia" (1931), em que há alguma coincidência de temas com o que Horkheimer discute, dentre eles a crítica à metafísica e ao positivismo, mas que, pela brevidade e intenção do texto, não são questionadas substancialmente.

A novidade desse capítulo é que a atenção está focada, não na metafísica em geral, mas no neotomismo. Nenhum autor pertencente a essa corrente é mencionado. $\mathrm{Na}$ crítica do positivismo, foi incluído o pragmatismo de John Dewey e de seu aluno, Sidney Hook, além de Ernst Nagel. Não resta dúvida disso, quando Horkheimer, em uma nota de rodapé no primeiro capítulo, pontifica que "o pragmatismo é visto [...] como uma expressão genuína da abordagem positivista.” (HORKHEIMER, 2015, p. 54). Neopositivismo e pragmatismo se confundem e, às vezes, são tratados pelo mesmo nome. Essa inclusão seguramente está associada ao fato de o autor ter morado nos Estados Unidos e ter tido maior contato com essa corrente, cuja difusão mais ampla aconteceu por aquelas bandas. Até antes de Eclipse da razão, as poucas referências de Horkheimer ao pragmatismo podiam ser encontradas em dois de seus ensaios de 1937 - "O mais novo ataque à metafísica" e "Teoria tradicional e teoria crítica".

O neopositivismo e o neotomismo são formas de resposta à crise cultural a que o autor se referiu, no primeiro capítulo da obra. Remédios contra todos os males que assolam a cultura contemporânea, são, contudo, panaceias conflitantes, pois cada tendência atribui à outra a responsabilidade pela crise da razão e prescreve uma receita específica, para seu combate. $\mathrm{O}$ neopositivismo insiste na necessidade de se manter a confiança nas realizaçóes da ciência e recusar qualquer solução metafísico-dogmática. Os intelectuais que apostam na revelação ou na intuição são "fracos dos nervos" (HORKHEIMER, 2015, p. 69). Por seu turno, o neotomismo parte da denúncia da razão formal, a qual começa a se formalizar na modernidade, imputando a ela as mazelas que assolam a humanidade. Propóe, assim, um retorno ao tomismo. A filosofia de Santo Tomás de Aquino conteria as bases para se resolver todos os problemas contemporâneos.

Horkheimer é enfático, ao criticar ambas as correntes. "Tanto o positivismo quanto o neotomismo são verdades limitadas, ignorantes da contradição inerente a seus princípios." (HORKHEIMER, 2015, p. 93). O positivismo, em sua ânsia por extirpar qualquer resquício metafísico do pensamento, fixa-se exclusivamente nos dados da experiência cuja sistematização em enunciados mínimos de significação constitui o ponto de partida 
para todo conhecimento verdadeiro. Esta é a pedra angular da ciência. O fato de ela servir a propósitos destrutivos é encarado como uma perversão da sua finalidade. O que, todavia, o positivismo não consegue enxergar é que sua credibilidade no potencial da ciência como chave para a resolução dos problemas humanos não tem fundamentação científica, é mera fé. Assim, os positivistas recaem em postulados metafísicos, algo que eles reiteradamente tentaram evitar. Por isso, o autor conclui: o positivismo é "uma filosofia pobre” (HORKHEIMER, p. 97), pois recusa a autorreflexão sobre seus pressupostos.

O neotomismo é anacrônico. Horkheimer insiste que, embora questionável, a filosofia de Santo Tomás de Aquino esteve relacionada com o tempo que a produziu. $\mathrm{O}$ neotomismo tenta apenas uma retomada da arquitetura conceitual tomista, como se ela coubesse nos moldes sociais do presente. $\mathrm{O}$ tomismo foi recomendado pela alta hierarquia católica, desde a segunda metade do século XIX, como filosofia a ser cultivada e encontrou vários filósofos dispostos a essa retomada. Horkheimer é radical contra essa tentativa. Ele assevera que revivificar filosofias ou mitologias do passado significa reconciliar o pensamento individual com as formas atuais de manipulação das massas. E exemplifica com a tentativa nacional-socialista de revivificação da mitologia pagã da Alemanha e seu uso como elemento da educação das massas.

Ao final do capítulo, Horkheimer é enfático, ao reconhecer que, de sua perspectiva de análise - a de "pensadores independentes que tentam opor-se aos poderes existentes" (HORKHEIMER, 2015, p. 73) - ambas as expressóes filosóficas são doutrinas afirmativas da realidade: "Uma tende a substituir a razão autônoma pelo automatismo da metodologia ultramoderna, a outra pela autoridade de um dogma." (HORKHEIMER, 2015, p. 104).

Os capítulos 1 e 2 formam um único bloco, que deve ser lido como o entendimento do autor sobre a "crise cultural presente" (cap. 1) e as falsas tentativas de remediá-la (cap. 2). Os capítulos 3 e 4 formam outro bloco, centrado na questão do indivíduo.

O capítulo 3 discute "A revolta da natureza", como resposta à dominação dessa mesma natureza. Reaparece aqui uma das teses centrais da Dialética do esclarecimento - "a dominação da natureza envolve a dominação do homem." (HORKHEIMER, 2015, p. 106). Não se trata especificamente da revolta da natureza externa, diante da avassaladora exploração a que é submetida pelo animal humano. $\mathrm{O}$ foco está direcionado à revolta da natureza interna 
do indivíduo. Essa discussão se liga com a do capítulo seguinte, intitulado "Ascensão e declínio do indivíduo". O capítulo 3 passa rapidamente em revista as filosofias de Descartes e Fichte, no que tange às relaçóes entre o eu e a natureza, para, em seguida, fixar-se em Freud. É o que se nota, quando Horkheimer começa a discutir o processo de formação do ego, enquanto estrutura de personalidade dos indivíduos. Ele destaca a centralidade da infância, nesse processo. Até os seis anos de idade, a criança já deve ter aprendido a superar seus impulsos imediatos e a substituí-los por gratificaçóes mediatizadas. Já deve ter conseguido também resolver sua relação amorosa com a mãe, superando, assim, o complexo de Édipo, mediante aceitação do princípio de autoridade, cuja referência está no pai. O fundamento do ego é a dominação de si, dos impulsos. "O ego domina a natureza" (HORKHEIMER, 2015, p. 121), ao dominar as paixôes.

A autorrenúncia é uma atividade do sujeito e ela possibilita a vida em sociedade. Esse processo formativo da estrutura de personalidade é completado, após a primeira infância, por outras instituiçóes, sobretudo a escola. Espera-se que, ao fim dele, o adulto tenha construído uma personalidade crítica, capaz de opor resistência aos imperativos sociais. Essa personalidade assim construída é denominada resistente, pelo filósofo. No entanto, pode haver rupturas ou falhas nesse processo e daí resultar um indivíduo acrítico, incapaz de opor resistência à realidade e propenso a se realizar na figura de outra pessoa, de um líder religioso ou político. Isso é o que Horkheimer chama de tipo submisso. Esse indivíduo não assimila o sentido da autorrenúncia, não vê nenhum ganho naquilo que a cultura ocidental lhe promete (a felicidade, a saúde e a riqueza). Por isso, sente ódio da civilização e está sempre propenso a manifestaçóes violentas contra aqueles que ele ou o líder a quem ele segue designa como inimigo. Sua estratégia de sobrevivência é a mimese. Ele se torna idêntico ao grupo de que participa e reproduz suas características. $\mathrm{O}$ impulso mimético contém uma força destrutiva, e um dos traços da sociedade atual é a manipulação dessa força, para o interesse de perpetuar a dominação. Por exemplo, o incitamento ao ódio contra os judeus, promovido pelo nacional-socialismo, explicaria por inteiro como se administra com eficiência a energia explosiva reprimida de indivíduos do tipo servil. "Ressentimento e fúria suprimida” (HORKHEIMER, 2015, p. 113) estão na base desse comportamento de ódio.

Se, no capítulo 3, a discussão do indivíduo recebe uma ênfase psicológica, no capítulo seguinte, ela é histórico-filosófica. Horkheimer começa por 
dizer que a crise da razão se vê acompanhada pela crise do indivíduo. Ressalta, logo em seguida, que a concepçáo de indivíduo diz respeito mais que a um ente singular, pois a esse ente se soma a consciência de individualidade. Assim, um indivíduo contemporâneo tem mais consciência de si do que um aborígene ou um romano da época de Nero ou um escudeiro medieval. A consciência de individualidade também parece estar ligada à condição cultural e econômica das pessoas. Isso seria verdadeiro, mais ainda nos dias de hoje, o que levaria à inferência de que atualmente a individualidade se realiza integralmente. Todavia, não é essa a tese que o autor quer comprovar. Ao contrário, ele sustenta que hoje a individualidade decresce a olhos vistos. $\mathrm{E}$ as razóes desse decréscimo são buscadas na história da filosofia. Assim, Horkheimer analisa a situação do indivíduo desde os tempos homéricos até os dias atuais. O ponto alto dessa análise é a ascensão da burguesia, o estabelecimento do capitalismo liberal e o surgimento do Iluminismo. São os três pilares que firmam o conceito de indivíduo e sua autonomia.

No entanto, assinala Horkheimer, o mesmo momento histórico que forja o indivíduo prepara a sua dissolução. A Revolução Industrial, que tem lugar nessa época, e a tendência do capitalismo à concentração econômica, verificada posteriormente, fazem ruir esse alicerce. Ambas desembocam respectivamente na sociedade industrial e no capitalismo avançado, os quais constituem os fundamentos do mundo administrado. Por analogia, Horkheimer diz, no início do capítulo, que o mundo administrado é como uma máquina que "ejetou o piloto" (HORKHEIMER, 2015, p. 143) e agora anda sozinha, "ela corre cegamente pelo espaço." Isso significa que a sociedade atual não precisa de indivíduos autônomos e pensantes, mas de pessoas que possam exercer tarefas para as quais foram designadas. Não à toa, em outros escritos, o filósofo assevera que essa sociedade consiste meramente num apertar de botôes, não importando se esses botôes são para chamar um elevador, acionar o semáforo vermelho para os veículos ou disparar uma ogiva nuclear.

Outro ponto alto do capítulo é a análise da situação das organizaçóes dos trabalhadores. Horkheimer mostra que a classe operária, antes entendida por Marx como negação do modo de produção capitalista, foi integrada à ordem que deveria negar. O filósofo pôde constatar, nos Estados Unidos, que os sindicatos se fortaleceram, a ponto de se constituírem em instituições tão sólidas e poderosas quanto as grandes corporaçôes industriais e financeiras, as quais deveriam ser combatidas pelo movimento operário. Os sindicatos tornaram-se diretamente interessados na manutenção da ordem econômica. Em vez 
de combater o capitalismo, eles se aliaram ao capital. Isso, no entendimento de Horkheimer, representa um passo a mais para o declínio do indivíduo. Ele afirma que "o fato de a organização do trabalho ser reconhecida como um negócio, como o de qualquer outra empresa, completa o processo de reificação do homem." (HORKHEIMER, 2015, p. 164).

A análise do movimento sindical está incluída na desconfiança que o autor manteve, diante de todos os "padrôes coletivos" (HORKHEIMER, 2015 , p. 156). Estes se tornaram refúgio para indivíduos fracos e submissos, e vão desde a indústria cultural - analisada mais detalhadamente, em Dialética do esclarecimento - até qualquer forma de organização social de que o indivíduo possa participar: os grupos de diversóes, os colegas de classe, a equipe desportiva. São lugares e situaçóes nos quais o indivíduo sacrifica suas possibilidades de realização, e seu comportamento é meramente adaptativo.

Em face da selva de coletivos do mundo administrado, Horkheimer vislumbra "forças de resistência", o que afasta sua análise de qualquer traço pessimista. Ele afirma: "É uma evidência contra o pessimismo social o fato de que, apesar do contínuo assalto de padróes coletivos, o espírito da humanidade esteja ainda vivo, se não no indivíduo como membro de grupos sociais, pelo menos no indivíduo na medida em que é deixado sozinho." (HORKHEIMER, 2015, p. 156). Dessa forma, Horkheimer deposita sua esperança no indivíduo resistente, aquele que é capaz de se comportar criticamente, diante da realidade, e não se rende aos coletivos. É esse tipo de personalidade que pode reverter a tendência ao declínio do indivíduo.

O capítulo 5 lança o olhar "Sobre o conceito de filosofia" e sintetiza o que foi, durante longo tempo, o projeto intelectual do autor: a reconciliação. Sob esse aspecto, Horkheimer é muito diferente de Adorno. Na Dialética do esclarecimento, o tema da reconciliação quase desaparece. Em Eclipse da razão, ele é explícito.

O filósofo propóe que a saída para a crise cultural, ou seja, a crise da razão (HORKHEIMER, 2015, p. 143) - "a doença da razão" (HORKHEIMER, 2015, p. 193) - consistiria na reconciliação, no âmbito teórico, dos dois lados da razão. Ele sustenta: "A tarefa da filosofia não é a de jogar, teimosamente, um conceito [de razão] contra o outro, mas a de promover uma crítica mútua e, assim, se possível, preparar no domínio 
intelectual a reconciliação dos dois na realidade." (HORKHEIMER, 2015, p. 191). O filósofo alimenta a expectativa de que essa reconciliação possa abrir caminho para sua realização, no domínio prático. Muito temeroso, no entanto, Horkheimer frisa que a filosofia não é um manual de receita. Mas ela pode, enquanto se dedica aos conceitos, propor essa reconciliação teórica. A reconciliação no domínio prático se daria entre o homem e a natureza: aquele deixaria de ser o dominador, e esta, mera matéria. Aparece, nessa indicação, o traço hegeliano do pensamento de Horkheimer: é um álibi contra a acusação de um romantismo da reconciliação. Contudo, Hegel é também lido criticamente. Afirmar que "a filosofia pode, por assim dizer, funcionar como um corretivo da história" (HORKHEIMER, 2015, p. 203) não significa a defesa de um espírito que atua na história, fazendo-a à revelia do querer humano. O Hegel filósofo da história importa menos do que o Hegel epistemólogo, cujo método dialético serviu de base para a crítica da razão. A orientação hegeliana, atravessada pelo crivo horkheimeriano, pode ser resumida pela ideia de que "a negação desempenha um papel crucial na filosofia." (HORKHEIMER, 2015, p. 200). E é justamente essa dialética como negação determinada que Horkheimer faz, ao evidenciar a insuficiência das soluçóes pragmatista e neotomista para a crise da razão.

Eclipse da razão apareceu pela primeira vez em tradução brasileira, em 1976, pela extinta editora Labor do Brasil. Não é uma tradução boa, contém erros e faltam partes ao seu conteúdo. Essa mesma tradução reapareceu pela editora Centauro, no começo da década de 2000, sem que os erros houvessem sido corrigidos. A que agora vem a lume, pela Editora da UNESP, é muito melhor, corrige os erros da anterior e foi feita por especialista na área, com conhecimento sobre o pensamento de Horkheimer. E, por isso, essa obra é indispensável para uma biblioteca mínima de teoria crítica. Ela é a primeira tradução de um projeto mais audacioso, o qual pretende difundir as ideias de um filósofo pouco lido no Brasil ou que, quando lido, quase sempre aparece em associação com Adorno, cujas ideias não são exatamente as mesmas.

\section{REFERÊNCIAS}

ADORNO, T.; HORKHEIMER, M. Dialética do esclarecimento. Tradução de Guido A. de Almeida. Rio de Janeiro: Jorge Zahar, 1985. 
SILVA, R. C.

WIGGERSHAUS, R. A Escola de Frankfurt: história, desenvolvimento teórico, significação política. Tradução do alemão por Lilyane Deroche-Gurgel. Tradução do francês por Vera de Azambuja Harvey. Rio de Janeiro: DIFEL, 2002.

Recebido: 12/01/2017

Aceito: $19 / 07 / 2018$ 